$1-1-1930$

\title{
Adjusting agricultural production and distribution in the Wheeling area to meet home market demands
}

W.W. Armentrout

Follow this and additional works at: https://researchrepository.wvu.edu/ wv_agricultural_and_forestry_experiment_station_bulletins

\section{Digital Commons Citation}

Armentrout, W. W., "Adjusting agricultural production and distribution in the Wheeling area to meet home market demands" (1930). West Virginia Agricultural and Forestry Experiment Station Bulletins. 228.

https://researchrepository.wvu.edu/wv_agricultural_and_forestry_experiment_station_bulletins/228 @ WVU. It has been accepted for inclusion in West Virginia Agricultural and Forestry Experiment Station Bulletins by an authorized administrator of The Research Repository @WVU. For more information, please contact ian.harmon@mail.wvu.edu. 


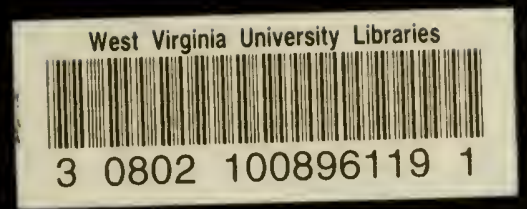



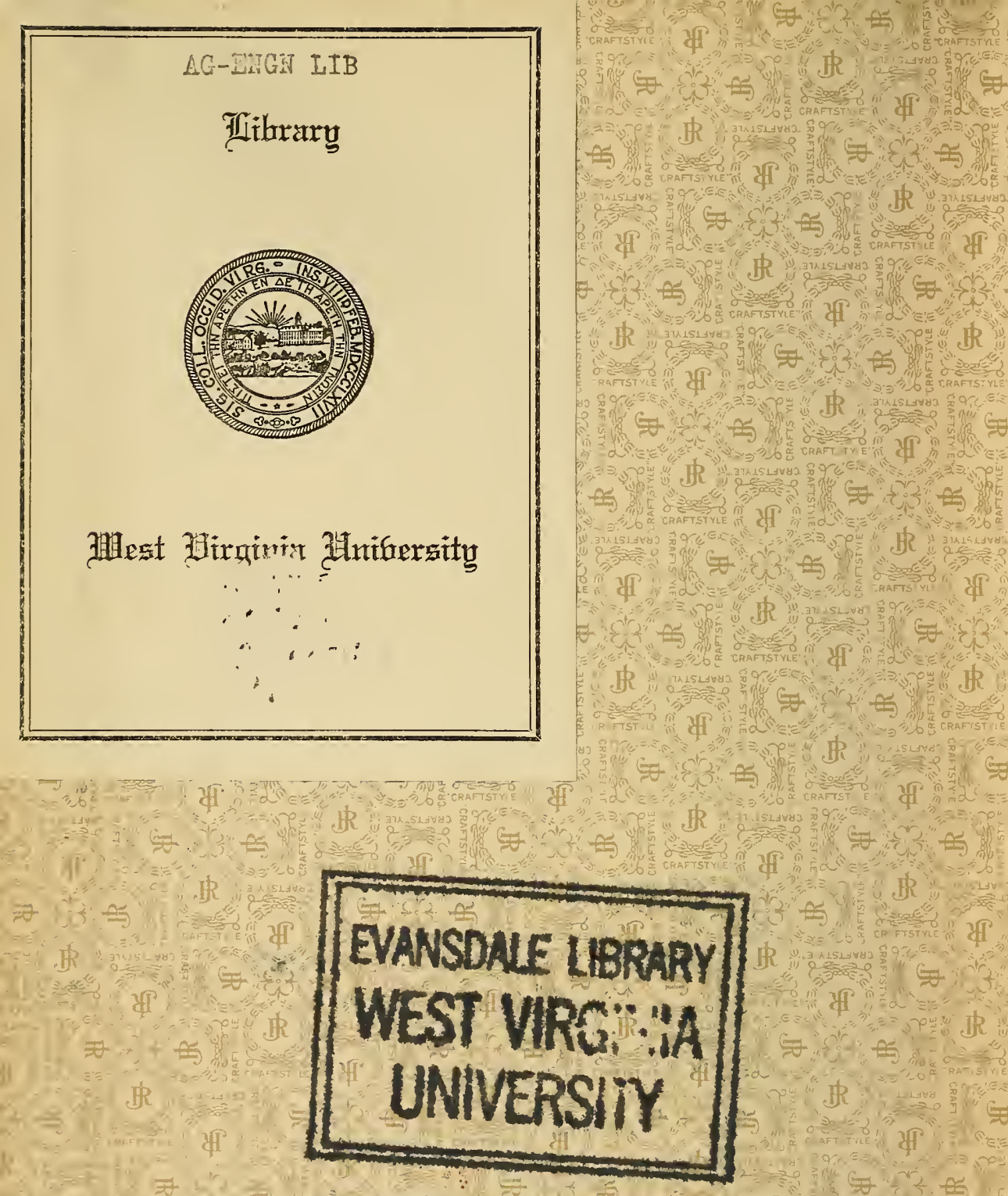


\section{West Virginia University Library}

This book is due on the date indicated

प1 $=25$ below.

R

舟

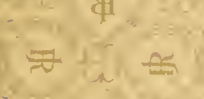

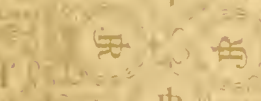

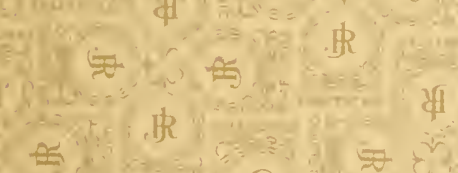

促

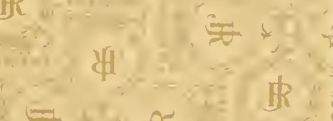

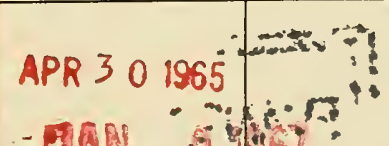

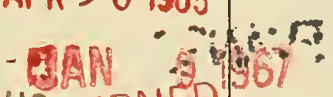

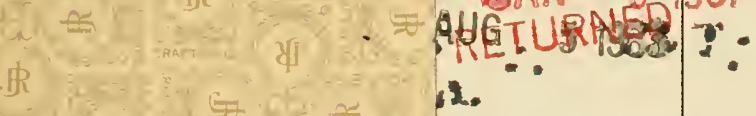

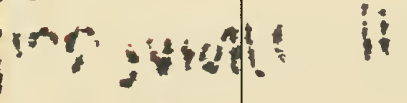

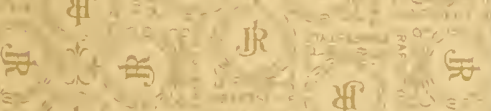

苋

$\Leftrightarrow c_{1}^{2}+5$ 
Digitized by the Internet Archive in 2010 with funding from

Lyrasis Members and Sloan Foundation 
Adjusting Agricultural Production and Distribution in the Wheeling Area to Meet Home Market Demands

by W. W. ARMENTROUT

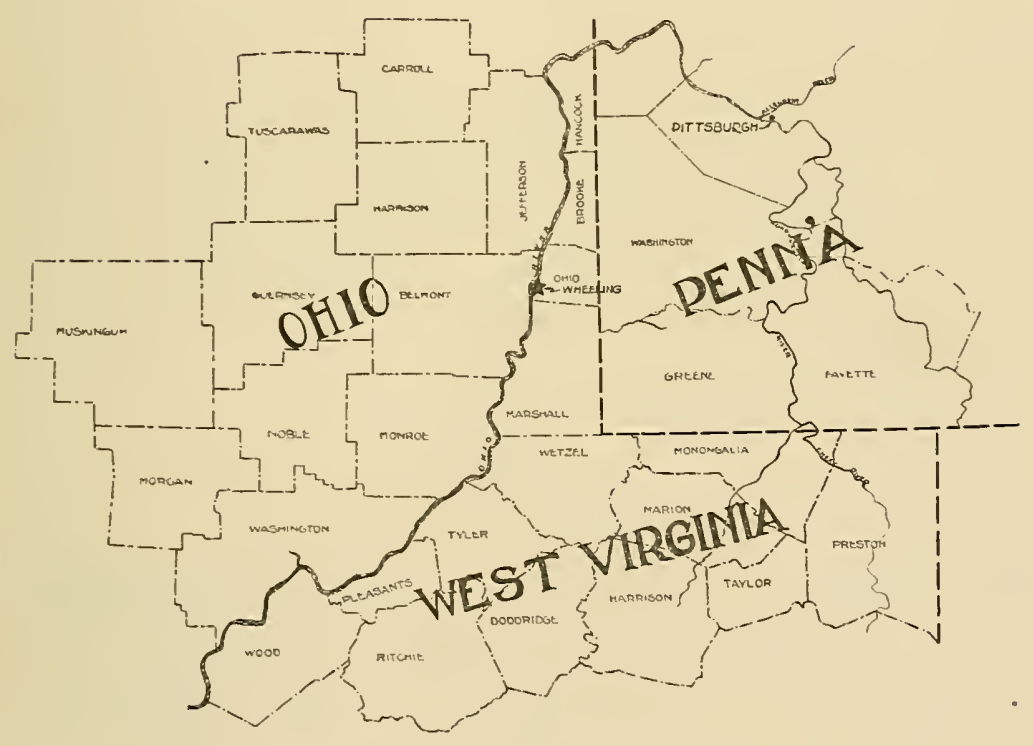

Extent of the Wheeling Area

AGRICULTURAL EXPERIMENT STATION COLLEGE OF AGRICULTURE, WEST VIRGINIA UNIVERSITY

F. D. FROMME, Director MORGANTOWN 


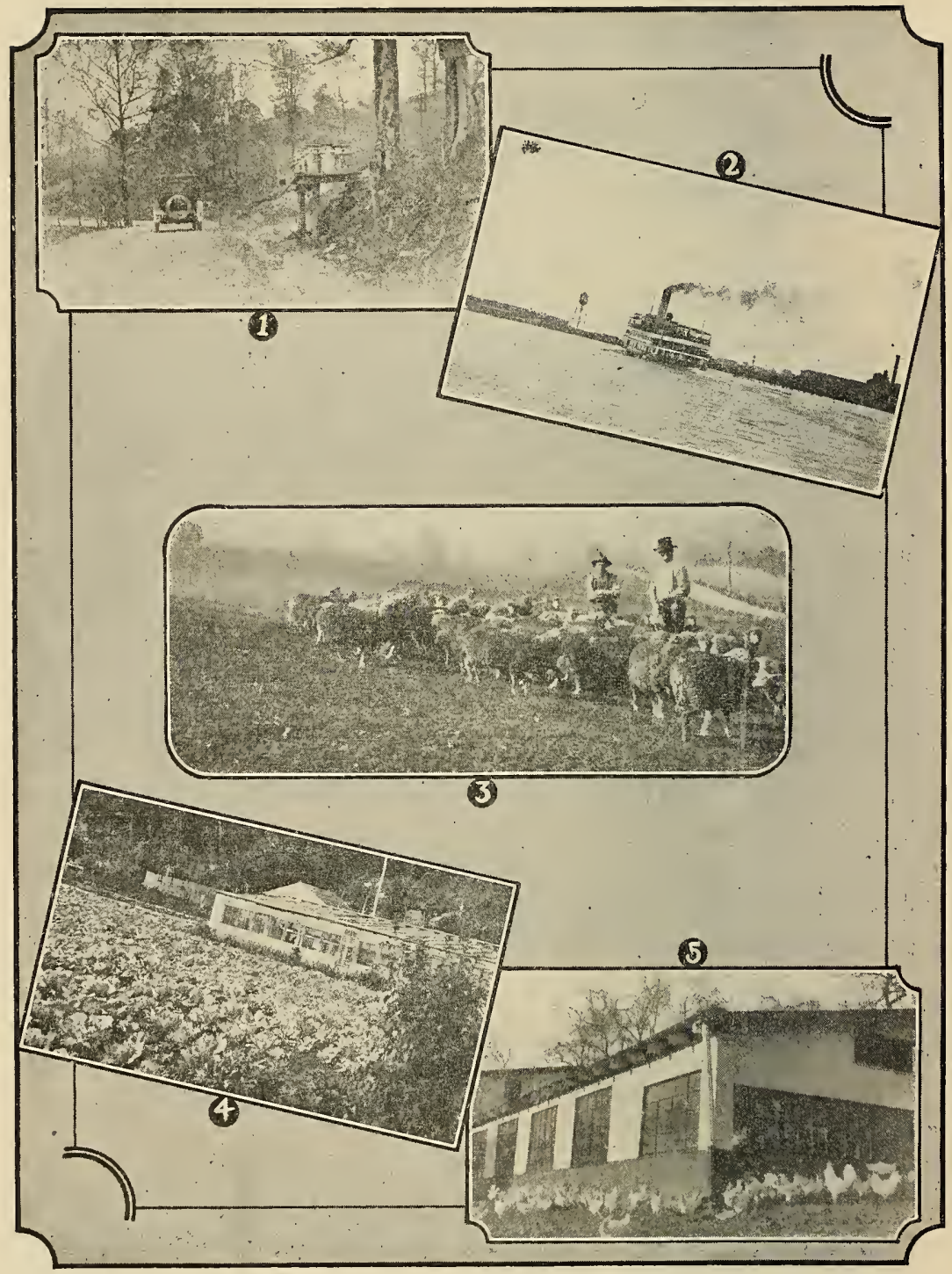

1. Waiting for the milk truck. Good roads made this possible.

2. Freight boats, plying the Ohio River, serve Wheeling.

3. Fine-wool sheep abound in this section.

4. A greenhouse adds value to small truck farms producing vegetables for the Wheeling market.

5. There are several commercial poultry flocks in the Wheeling area. 


\section{Adjusting Agricultural Production and Distribution to Meet Home Market Demands in the Wheeling Area*}

by W. W. ARMENTROUT

$\mathrm{T}$ HIS report is the fourth of a series of studies of consumption of farm products in the larger cities of West Virginia and of production in the agricultural sections surrounding them. ${ }^{1}$

It is the report of a study of receipts of food commodities in Wheeling for a twelve-months' period beginning June 1, 1925, and ending May 31, 1926. Because of the geographical locatiun of Wheeling, with very little of its agricultural section lying within the borders of West Virginia, no detailed study was made of nearby farm production. While Ohio County, in which Wheeling is situated, contributes considerably to the food supply of the city, it is apparent to any one familiar with the section that a large part of the locally produced commodities which reach the market come from the neighboring states of Ohio and Pennsylvania."

The study was limited to obtaining (1) a record of the quantity of certain food commodities which passed through the Wheeling market, exclusive of locally produced goods transported over highways; (2) the section of the country from which the commodities came; and (3) the transportation charges.

*Submitted for publication August, 1927.

IStudies of the Charleston, Clarksburg, and Beckley areas are reporced in IV. Va. Agr. Exp. Sta. Bulletins 1S 8,212 , and 226 , respectively.

2No satisfactory plans were formulated with Ohio and Pennsylvania for a cooperative study. It seemed probable that data on local production such as could be obtained in the limited Wheeling area confined to West Tirginia might prove misleading. 
The quantity of various commodities coming on the market indicated a demand which was not satisfied by local production. A record of the section of country from which the commodities came will enable local producers to locate their competitors and provicle a basis for studying their production costs. The transportation charges show the advantage which nearness to market affords local producers over their competitors.

This study is limited in character. While a knowledge of market demand in terms of quantity is one important guide to production, the producer should also know the market demand in terms of variety and quality of product, as well as his own cost of production in comparison with that of his competitors. There is, therefore, need that this study be continued to cover the market demands in terris of variety, quality, grade and pack, and production costs.

\section{PURPOSE OF THE STUDY}

The purpose of this and similar studies has been stated in Bulletins 188 and 212. Shifts in population and changes in production in competing sections are among the factors which make adjustments in farm production desirable from time to time if the greatest returns are to be obtained. While industry faces the need for continual changes, the size of the unit makes changes easier than in agriculture. The chief aim of the present report is to present information not readily obtainable by the individual farmer which may help farmers in West Virginia to adjust their production to meet changing conditions.

\section{SOURCES OF DATA}

The data on freight receipts were taken from the station records of the Wheeling stations of the Baltimore and Ohio Railroad, the Pennsylvania Railroad, and the Wheeling and Lake Erie Railway. Records of express receipts were obtained from the division accounting offices of the American Railway Express Company, located in Pittsburgh. Records of receipts by boat were obtained from freight records on the "Senator Cordill" and the "Helen E" freighters."

The method used in this study and the source of the data malie it possible to present accurately the section of country from which commodities came, the quantity of receipts, and the carrying charges.

${ }^{3} \mathrm{~A}$ complete record of receipts for all boats serving the Wheeling market was not available. 


\section{AGRICULTURE OF THE WHEELING AREA}

Wheeling with its suburbs covers a large part of Ohio County. In recent years there has been extensive suburban development; people of means have built homes, some of them estates, out in the open country. This movement has resulted in increased land values. Consequently, under the present system of farming, values placed on the land are out of all proportion to its earning capacity as farm land. Some land has changed hands at these high prices, while much of the remaining farm land has assumed suburlan values and is held and taxed accordingly. Uuder such conditions it is discouriging to attempt to show adecunte earmmg puwers for the land when used for agricultural purposes.

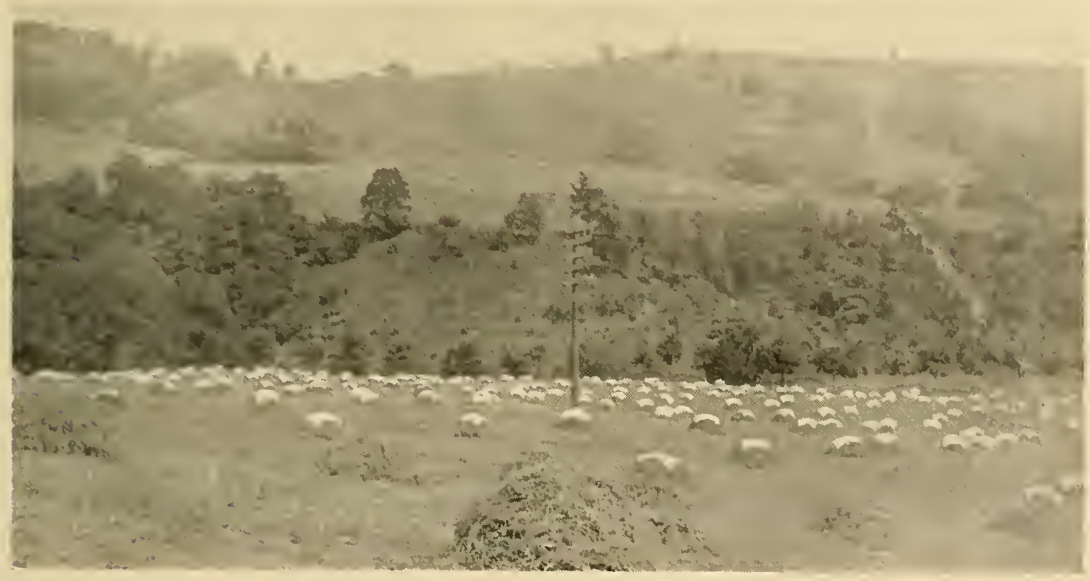

Most of the farm land in Ohio County is rolling or hilly.

There is a considerable acreage of fertile land in Ohio County well adapted for agricultural purposes. If the owner has not paid suburban prices for it and is willing to discount its paper value to the level of agricultural land value, he should be able to realize at least average returns from it.

The greater part of the land in Ohio County is hilly to rolling, but much of it has a good deep soil. Three or four sections of creek bottom in the county are well adapted to truck farming. Good tarning sections are also found to the north in Brooke County and to the south in Marshall and Wetzel Counties. West Virginia. Across the Ohio River in Ohio lies a splendid farming section with a network of hard-surfaced highways which make the Wheeling market reacily accessible. 
Dairy farming ranks first in importance in Ohio County. In recent years it has shown rapid development in neighboring West Virginia counties as well as across the Ohio River. There is considerable truck farming in the region but indications are that such farming has lost rather than gained in favor, probably because much of the good truck land near Wheeling has been taken over for factory sites and for summer camps.

There are several specialized poultry farms, and the farm flock is an important source of income to a majority of the farmers. There are a number of commercial orchards in Brooke County and also across the river in Ohio. Sheep grazing holds considerable iruportance in the area, but it contributes little to the food supply, since the fine-wool breeds predominate.

\section{RAILWAYS, HIGHWAYS, AND POPULATION}

Wheeling is served by three railroads-the Baltimore and Ohio Railroad, the Pennsylvania Railroad, and the Wheeling and Lake Erie Railway. Boats ply the Ohio and Kanawha Rivers from Pittsburgh to Charleston, West Virginia, and the Ohio River to Cincinnati, and two or three small freight boats make shorter runs down the Ohio River from Wheeling.

The city is served by a highway system which reaches far out into the agricultural sections and makes it possible for producers. though miles away, easily to market their products by truck.

The population of Wheeling is about 56,000 . Its wholesale groceries serve a population of approximately $360,000 .^{4}$

\section{RECEIPTS OF FOOD COMMODITIES IN WHEELING}

The commodities included in this study are potatoes, cabbage: onions, lettuce, tomatoes, beans, corn, melons, miscellaneous vegetables, apples, peaches, grapes, poultry, eggs, milk (condensed). butter, cheese, hay, grain and mill feeds, cattie, and hogs.

Each of these commodities was being produced in some quantity in the agricultural area surrounding Wheeling, the area being more or less suited to such production in so far as physical adaptations are concerned.

These data do not show the full market demands, since the locally produced commodities which reached the market were not considered.

${ }^{4}$ Atlas of Wholesale Grocery Territories, U. S. Department of Commerce, 1927. 
On the other hand, not all the commodities shown as received in Wheeling were consumed there, but were consumed within Whecling's trade arcal. 'This circumstance, however, does not affect the significance of these data as a measure of the market demand.

\section{Potatoes}

Table 1 shows the receipts of potatoes in Wheeling by freight and by boat for the twelye-months' period beginning June 1. 1925, and ending May 31, 1926.

The receipts totalled $18,962,991$ pounds or $316,0 \div 6$ bushe!s. Of this quantity 266,688 pounds, or 4,445 bushels came from points in West Virginia. This is about 1.4 percent of the total.

West Virginia supplied $\&$ percent of the potatoes receives in Clarksburg during the preceding twelve-months' period. ${ }^{5}$ There was 110 noticeable shortage in yield of potatoes during the later period.

During the four-months' period, August, September, October and November, over which most of the West Virginia potatoes are marketed, Wheeling received 7,135.861 polinds, 3.7 percent of which was shipped from points in West Virginia. During this same period of the previous year WVest Virginia supplied approximately 20 percent of the potatoes received in Clarksburg. ${ }^{6}$

Carrying charges on potatoes amounted to $\$ 94,515.45$, or an average of $50 \mathrm{c}$ per cwt. The average carrying charges on potatoes received from West Virginia were $28 \mathrm{c}$ per cwt. This gives West Virginia producers a margin of $22 \mathrm{c}$ in transportation costs over their competitors, or practically the same advantage found for West Virginia nroducers on the Clarksburg market.'

No new data on cost of production or prices of potatoes have been collected by this Station since the publication of the Clarksburg study. The data on cost of production and prices as presented in West Virginia Agricultural Experiment Station Bulletin 212, pages 17-26, are applicable to the Wheeling area.

West Virginia producers have scarcely touched the potato 1:arket of Wheeling. From previous studies as well as several known cases of profitable potato production, there appears to be ample justification for promoting potato production in sections of the state w!lere physical conditions are adapted to their culture.

ธIV. Va. Agr. Exp. Sta. Bul. 212, p. 11.

6W. Va. Agr. Exp. Sta. Bul. 212 , p. 15. 


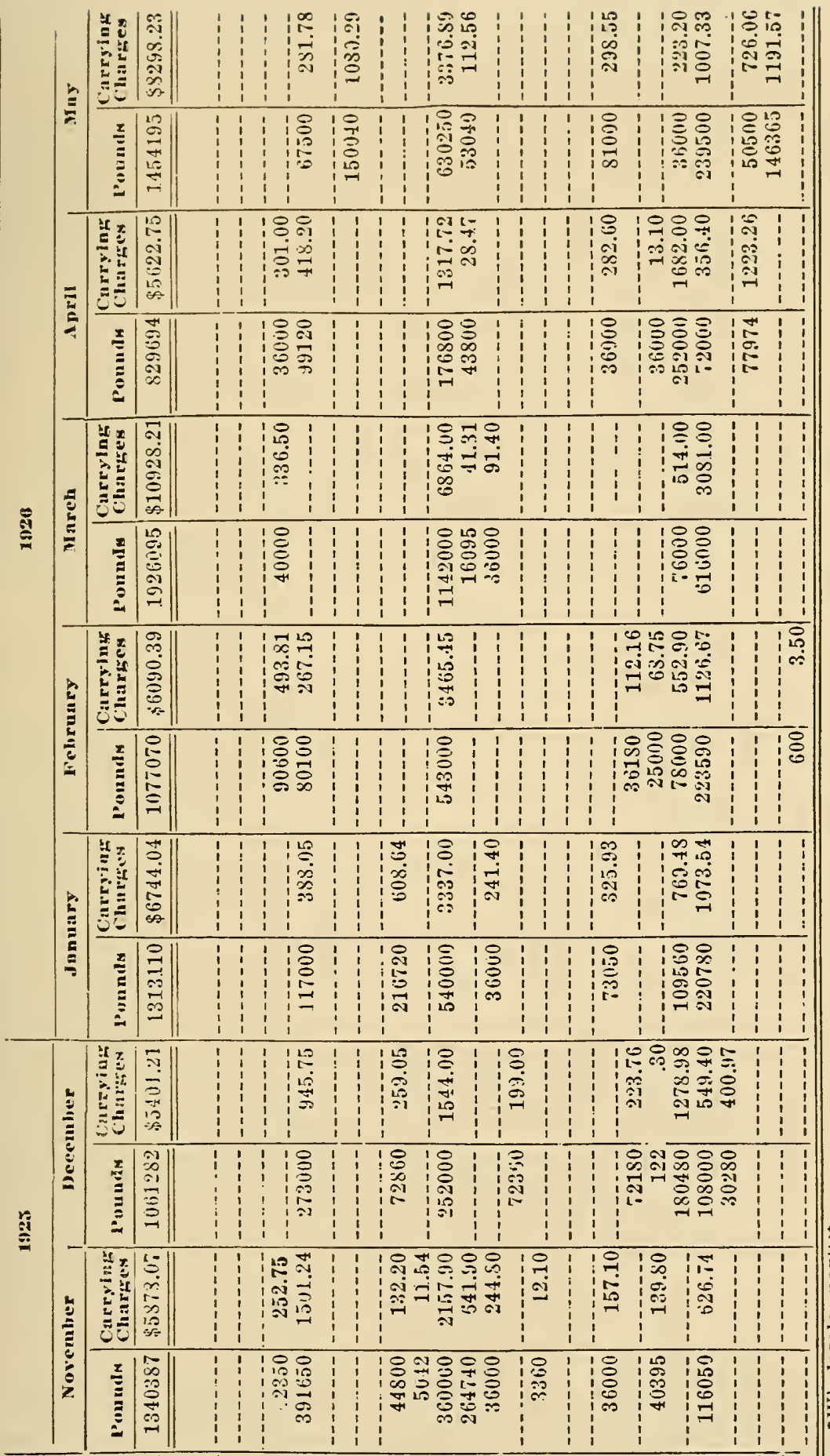

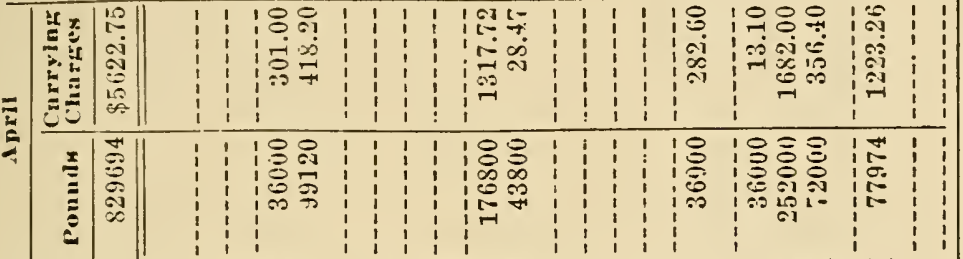

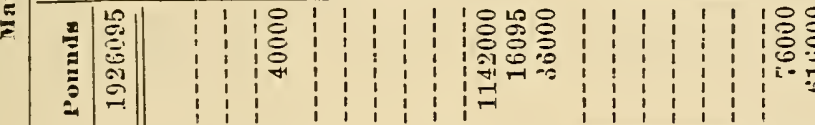

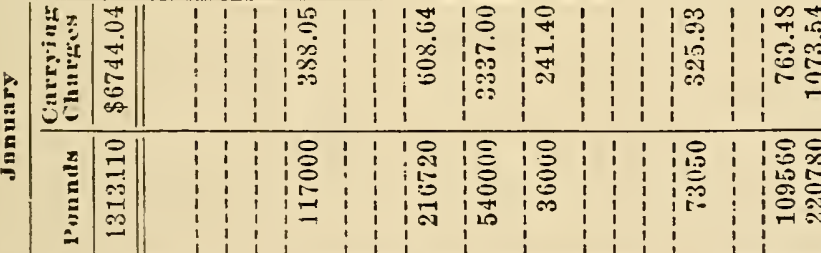

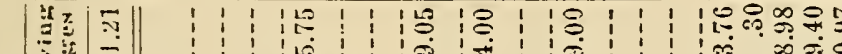

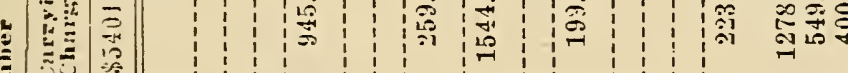

エ

弱

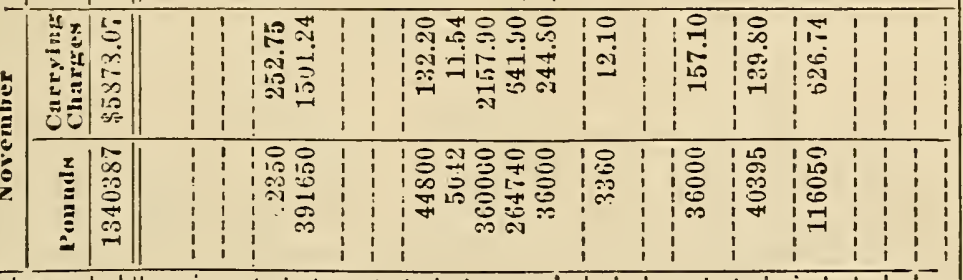

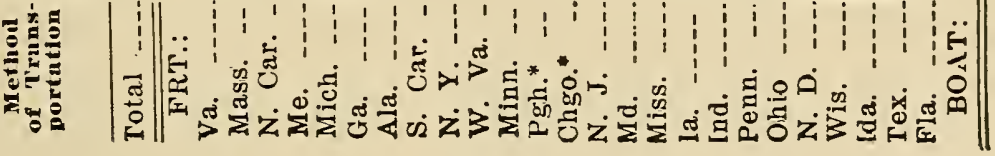




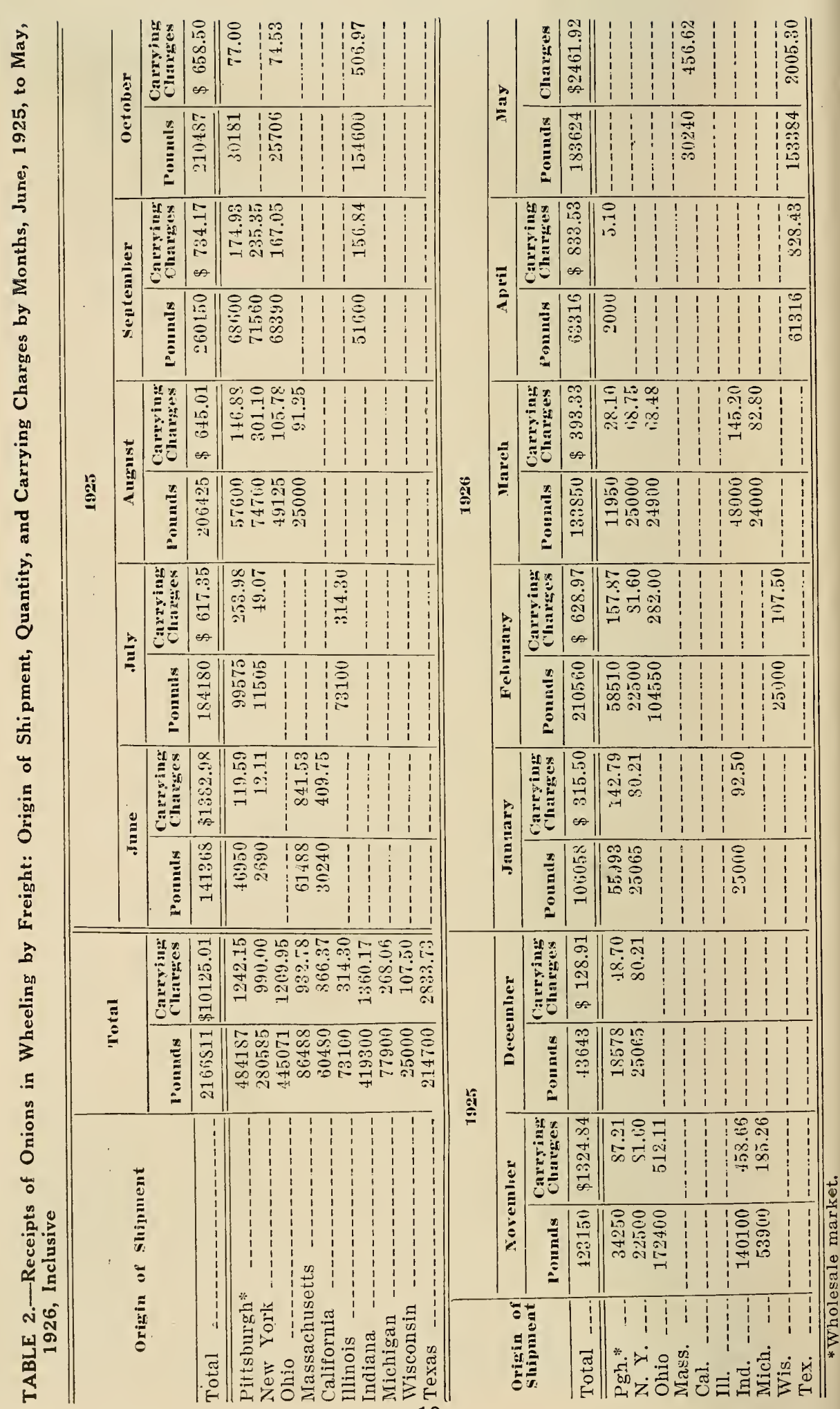




\section{Onions}

Table 2 show's the receipts of onions on the Wheeling market, amounting to 2,166,\$11 pounds, with carrying charges of $\$ 10,125.01$. West Virginia did not supply any of this quantity. Ohio supplied more onions than any other state. Indiana ranked second.

\section{Cabbage}

Table 3 shows the receipts of 2,876,676 pounds of cabbage, with carrying charges anounting to $\$ 16,903.00$. New York ranks first in quantity of shipments. Ohio supplied a sull quantity (77,000 pounds), while no shipments came from West Virginia. Shipnents of cabbage were received every month of the year, -abundant evidence of opportunity to increase local production at any period when clinatic conditions permit.

\section{Tomatoes}

Table 4 shows the receipts of tomatoes on the Wheeling market. A total of $86+, 333$ pounds, with carrying charges amounting to $\$ 7,322.74$, were received. Texas contributed nore than any ctlier statc, while only a few came from West Virginia and Ohio. At the time home grown tomatoes were in season, however, very few were received from producing areas other than Ohio and West Virginia. Some tomatoes were received fron the wholesale markets of Pittsburgh chring each month of the year. Nost of the tomatoes siomin as express receipts cane from Pittsburgh and points in Ohio. The boat shipments for the most part came from tire Marictta, Ohio, section, with very few from the West Virginia side.

The Wheeling market presents conditions parallel with those of the Clarksburg and Charleston markets in the matter of tomato supply. Local production practically takes care of demand during the local producing season. Any material increase should occur in "outof-season" production, but sufficient data are not at hand to judge the profitableness of such an undertaking.

\section{Lettuce}

In Table 5 the receipts of lettuce on the Wheeling market are presented. The receipts by express and freight anounted to 1,122,098 pounds, with carrying charges of $\$ 12,210.37$. Some lettuce was received during each month of the year. Express shipments came princi- 


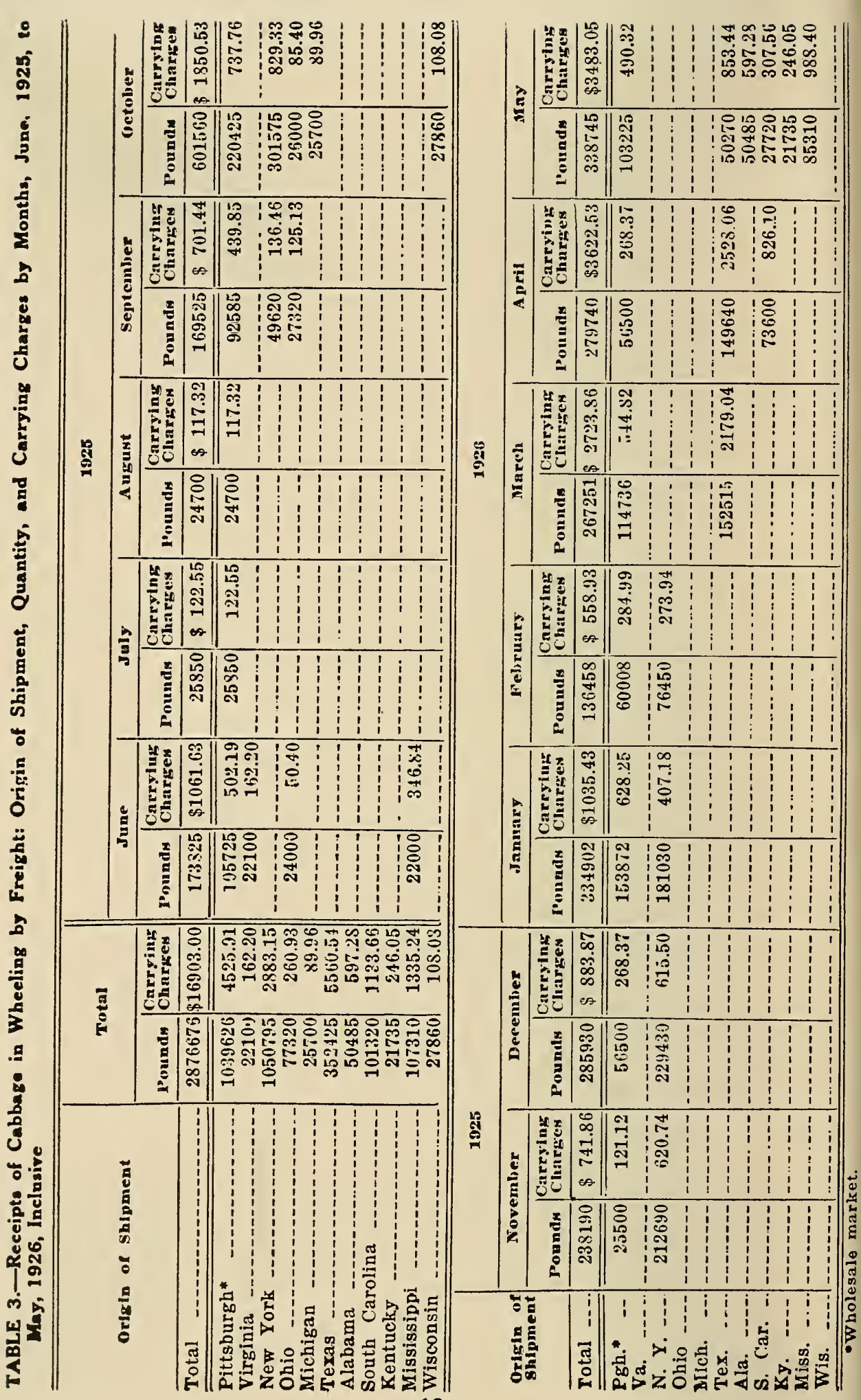




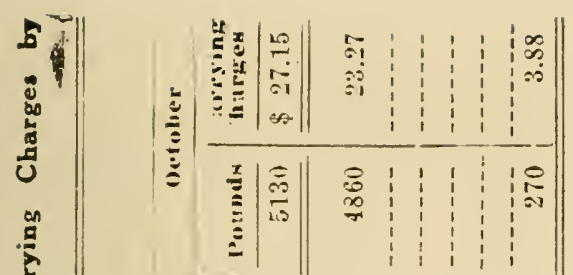

U్

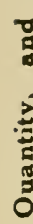

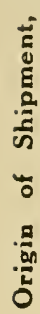

离

离

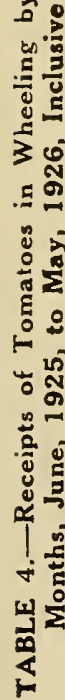

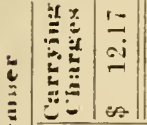

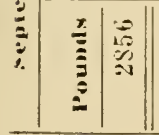

| 4. i

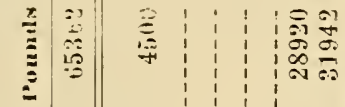

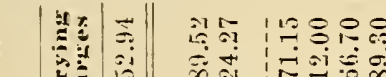
is

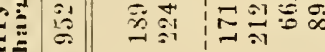
我

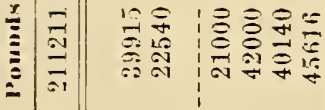

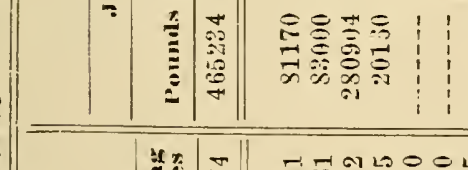

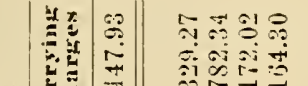

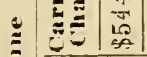

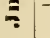

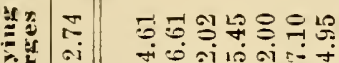

吾

总

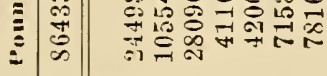

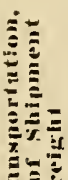

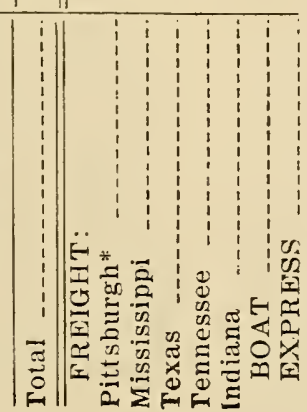

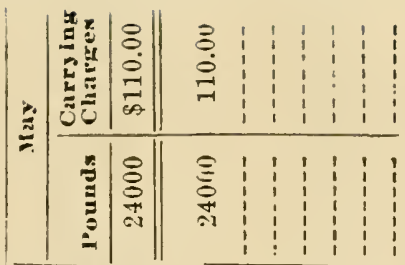

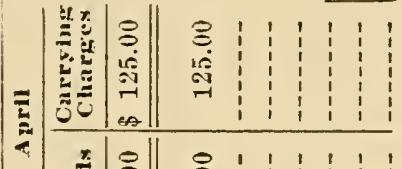

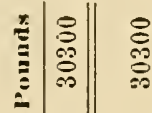

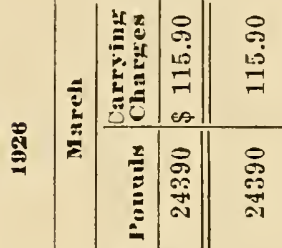

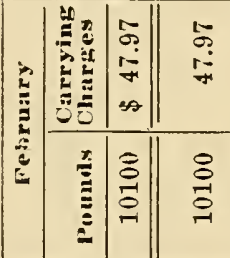

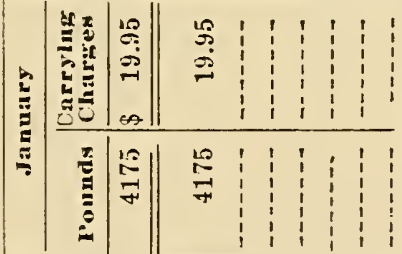

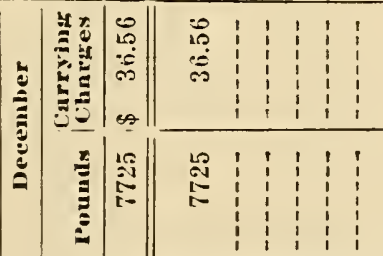

要

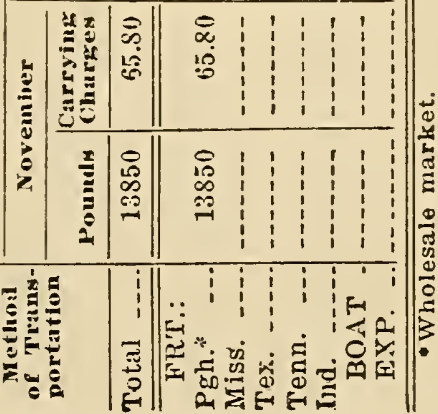


pally from Ohio. Freight shipunents canne from Ohio, California, and Arizona, with many small shipments from l'ittsburgh which in all probability were California and Arizona lettuce. The average carrying charge for the total receipts was $\$ 1.09$ per cwt., while the average carrying charge for the California shipments was \$1.8S per cwt. This high carrying charge gives local producers a considerable margin over their competitors in California and Arizona. Some leaf lettuce is grown locally, but no great success in growing head lettuce has been experienced. Consumers seem to prefer head lettuce to the leaf lettuce varieties, and for this reason local producers may not be able to mect competition from California and Arizona.

\section{Miscellaneous Vegetables}

Table 6 shows the receipts of miscellaneous regetables on the Wheeling market. Included are such regetabies as peppers, cucumbers, celery, green beans, and green corn. The larger part of these shipments came from the wholesale marliets of Pittsburgh and Columbus.

\section{Poultry and Eggs}

Table 7 shows the express receipts of poultry on the Wheeling market. Some poultry was brought to Wheeling by boat, but the records were not sufficient to permit of even a reliable estimate. No shipments came by freight. The 225,331 pounds of poultry came from points in Ohio and West Virginia, no shipments being noted from other states.

Table 8 shows that 20,866 cases of eggs were received on the Wheeling market by freight, boat, and express. The shipments by boat and express came from points in Ohio and West Virginia. The record would indicate that local demands are reasonably well met by local production, yet with some opportunity for expansion of the industry.

\section{Dairy Products}

Dairy farming in the Wheeling area in the past two years has met with reverses, and much dissatisfaction and controversy has developed on the part of the dairy farmers. A few years ago there was considerable expansion in the production of market milk in Ohio County. There is nothing to indicate that this was not a healthy expansion, prompted by the demand for fluid milk. Within the last few 


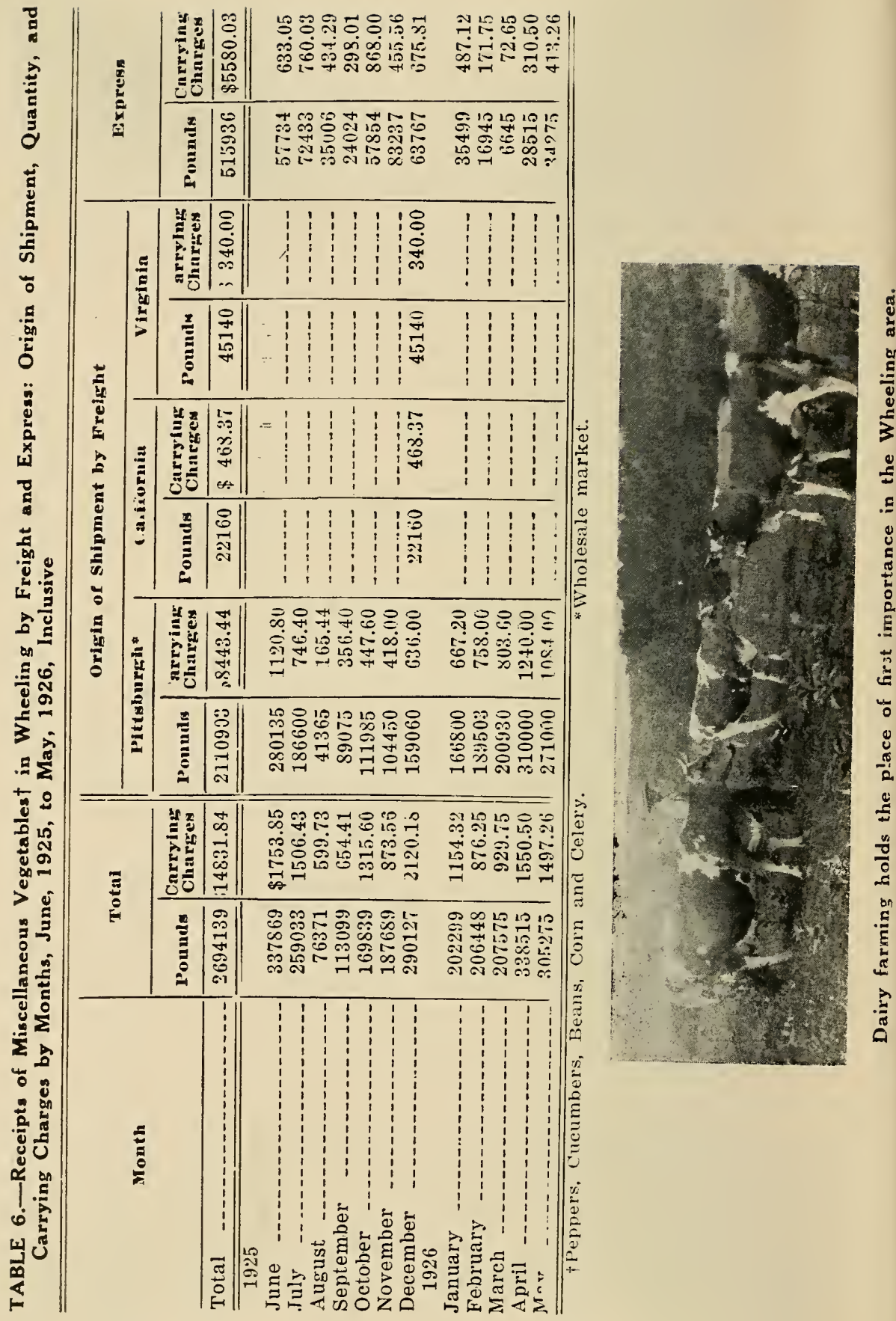


TABLE 8.-Receipts of Eggs in Wheeling by Freight, Express, and Boat: Origin of Shipment, Quantity, and Carrying Charges by Months, June, 1925, to May, 1926, Inclusive

\begin{tabular}{|c|c|c|c|c|c|c|c|c|}
\hline & & & \multicolumn{6}{|c|}{ Origin of Shipuent by Freight } \\
\hline \multirow{2}{*}{\multicolumn{3}{|c|}{ Mouth }} & \multicolumn{2}{|c|}{ Total } & \multicolumn{2}{|c|}{ Chicago* } & \multicolumn{2}{|c|}{ Iovva } \\
\hline & & & Cases & 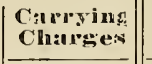 & Cases & 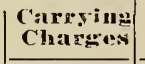 & Cases & $\begin{array}{l}\text { Cacrying } \\
\text { Chumes }\end{array}$ \\
\hline \multicolumn{3}{|c|}{ Total $----\cdots$} & 20866 & $\$ 7546.80$ & 6021 & $\$ 20 \$ 9.85$ & 2000 & $\$ 725.02$ \\
\hline \multicolumn{3}{|c|}{1925} & & & & & & \\
\hline \multirow{4}{*}{\multicolumn{3}{|c|}{$\begin{array}{l}\text { June } \\
\text { July } \\
\text { August } \\
\text { September }\end{array}$}} & 2171 & 712.51 & 254 & 112.30 & ------ & ----- \\
\hline & & & 1162 & $499.8 \%$ & 655 & 267.58 & $-\cdots---$ & ----- \\
\hline & & & 1807 & 751.87 & 1205 & 479.08 & $-----\infty$ & $---n$ \\
\hline & & & 844 & $312 . .36$ & $-\cdots--$ & $\ldots-\cdots$ & 400 & 125.08 \\
\hline \multicolumn{3}{|c|}{ October } & 2186 & 715.62 & 1232 & 372.17 & 400 & 122.96 \\
\hline \multicolumn{3}{|c|}{ November } & 3355 & 1106.20 & 1645 & 434.43 & 800 & 365.68 \\
\hline \multicolumn{3}{|c|}{$\begin{array}{l}\text { December } \\
\quad 1926\end{array}$} & 1242 & 552.14 & 565 & 216.71 & ----- & $\cdots---\infty$ \\
\hline \multicolumn{3}{|c|}{ January } & 1814 & 676.53 & 215 & 94.58 & 400 & 111.20 \\
\hline \multirow{2}{*}{\multicolumn{3}{|c|}{$\begin{array}{l}\text { February } \\
\text { March }\end{array}$}} & 1993 & 351.39 & 250 & 112.00 & ------ & ----- \\
\hline & & & 2276 & 914.17 & ----- & $-\cdots--$ & ----- & ------ \\
\hline \multicolumn{3}{|c|}{ April } & 1170 & 566.75 & $-\cdots-\cdots$ & $-\cdots$ & $---\cdots$ & ------ \\
\hline \multicolumn{3}{|c|}{ May $---\cdots-1$} & 841 & $441, .33$ & $\ddot{-\rightarrow-n--}$ & $--\cdots--$ & $--\cdots$ & ----- \\
\hline \multirow{3}{*}{ Month } & \multicolumn{4}{|c|}{ Origin of Shipment hy Freiglnt } & \multirow{2}{*}{\multicolumn{2}{|c|}{ Express }} & \multirow{2}{*}{\multicolumn{2}{|c|}{ Boat }} \\
\hline & \multicolumn{2}{|c|}{ Ohio } & \multicolumn{2}{|c|}{ Miscellaneous } & & & & \\
\hline & Calses & $\begin{array}{l}\text { Carrying } \\
\text { Clonkes } \\
\end{array}$ & Cases & $\mid \begin{array}{l}\text { Camrytug } \\
\text { Chatigen }\end{array}$ & Cuses & $\begin{array}{l}\text { Carryiug } \\
\text { Chourges }\end{array}$ & Carses & $\begin{array}{l}\text { Carrying } \\
\text { Charges }\end{array}$ \\
\hline Total $\ldots-\cdots$ & 3130 & $\$ 728.26$ & 105 & 25.82 & 9346 & $\$ 3907.15$ & 264 & $\$ 70.70$ \\
\hline 1925 & & & & & & & & \\
\hline June & 1390 & . 335.89 & 9 & 2.43 & 518 & 260.89 & $----\cdots$ & ----- \\
\hline July _...- & 85 & 21.63 & ----- & ----- & 422 & 210.66 & -- & $---\infty$ \\
\hline August $\ldots$ & 58 & 14.75 & ----- & $---\cdots$ & 534 & 255.84 & 10 & 2.20 \\
\hline September & 86 & 23.15 & $-\infty-\infty$ & $-\cdots--$ & 349 & 162.15 & 9 & 1.98 \\
\hline October -- & 210 & 50.55 & ------ & $-\cdots--$ & 333 & 161.24 & 11 & 2.70 \\
\hline November & 475 & (4) $\quad 82.72$ & $-----\infty$ & ----- & 426 & 219.57 & 9 & 4.50 \\
\hline $\begin{array}{l}\text { December } \\
1926\end{array}$ & 40 & $11.4 \tilde{0}$ & ------ & ------ & 624 & 317.78 & 13 & 6.50 \\
\hline January -- & 400 & 75.47 & 25 & 8.00 & 774 & 387.18 & $\cdots$ & $----\overline{1}$ \\
\hline February - & 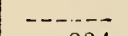 & ------ & 50 & 10.94 & 1692 & 227.13 & 0 & 1.32 \\
\hline March --- & 234 & $63.2 \bar{\jmath}$ & $---n-$ & ------ & $18 i^{2}, 2$ & 805.92 & 180 & 45.00 \\
\hline April & 152 & 43.40 & 12 & 316 & 980 & 453.69 & 26 & 6.50 \\
\hline May $\sim---$ & $\sim----$ & $1 \ldots$ & 9 & 1.29 & $8: 32$ & $445 . .10$ & & $-\cdots---$ \\
\hline
\end{tabular}

*Wholesale market.

producers were selling whole milk at from 25c to $60 \mathrm{c}$ per grillon. Other producers were selling whole milk at as low as $20 \mathrm{c}$ per gailon wholesale. None of the ten producers interviewed was losing money on his milk; some were making but small margins of profit; others were making fairly satisfactory profits. With the volume of business involved, the margin of profit on milk was not sufficient for the most economical producers to make more than fairly good wages. 
'lable 9 show's the receipts of condensed milk on the Wh eling market.

Table 10 shows the receipts of cheese on the Whecling mariset.

Table 11 shows the receipts of oleomargarine on the Wheling market.

TABLE 9.-Receipts of Condensed Milk in Wheeling by Freight: Quantily and Carrying Charges by Months, June, 1925, to May, 1926, Inclusive

\begin{tabular}{|c|c|c|}
\hline Month & Quantity in Ponuls & Carrying Charges \\
\hline Total $\ldots$ & 1759227 & $\$ 5945.71$ \\
\hline 1925 & & \\
\hline June - & $18: 5522$ & 751.39 \\
\hline July & 443668 & 1367.83 \\
\hline 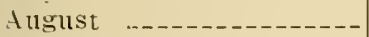 & 70196 & 165.27 \\
\hline September & $11 \$ 629$ & 332.24 \\
\hline October & 98773 & 377.22 \\
\hline November & $\$ 6456$ & 337.61 \\
\hline $\begin{array}{l}\text { December } \\
1926\end{array}$ & 123226 & 345.31 \\
\hline January & 210280 & 662.20 \\
\hline February & 165742 & 597.74 \\
\hline March & 81479 & 280.31 \\
\hline April _. & 91346 & 382.69 \\
\hline May & 79910 & 315.91 \\
\hline
\end{tabular}

TABLE 10.-Receipts of Cheese in Wheeling by Freight and Express: Zunntity and Carrying Charges by Months, June, 1925, to May, 1926, Inclusive

\begin{tabular}{|c|c|c|}
\hline Yonth & Qunutity in Poumls & Carrying Charies \\
\hline Total _. & 1903649 & $\$ 15912.60$ \\
\hline 1925 & & \\
\hline - n & 148112 & 1341.38 \\
\hline July & 202910 & 1935.00 \\
\hline August ...- & 213266 & 1035.47 \\
\hline September & $146 ? 05$ & 144.2 .31 \\
\hline October & 239171 & 2070.67 \\
\hline November & 127057 & $1116.0 \mathrm{~S}$ \\
\hline $\begin{array}{l}\text { December } \\
1926\end{array}$ & 147119 & 1251.48 \\
\hline January & 131510 & 1199.30 \\
\hline February & 172734 & 1191.50 \\
\hline March & $170 \$ 68$ & 1516.55 \\
\hline April & 102542 & 946.27 \\
\hline May & $10,0.55$ & $72 \curvearrowleft .09$ \\
\hline
\end{tabular}


TABLE 11.-Receipts of Oleomargarine in Wheeling by Freight and Express: Quantity and Carrying Charges by Months, June, 1925, to May, 1926, Inclusive

\begin{tabular}{|c|c|c|}
\hline Month & Quantity in Poundy & Carrying Charges \\
\hline Total & 976508 & $\$ 7537.03$ \\
\hline 1925 & & \\
\hline June & 55775 & 507.15 \\
\hline July & 7.3650 & 572.42 \\
\hline August & 102473 & 820.70 \\
\hline September & 76614 & 657.85 \\
\hline October & 77262 & 527.80 \\
\hline November & 92161 & 532.11 \\
\hline $\begin{array}{l}\text { December } \\
1926\end{array}$ & 86226 & 571.13 \\
\hline January & 1036,88 & 845.15 \\
\hline February & 883998 & 625.29 \\
\hline March & 57357 & 502.81 \\
\hline April & 82263 & 634.39 \\
\hline May & 77641 & 630.23 \\
\hline
\end{tabular}

\section{Fruits}

\section{Peaches}

Table 12 shows the receipts of peaches on the Wheeling market. Apples

Table 13 shows the receipts of approximately 125,000 bushels of apples on the Wheeling market. New York ranks first in terms of quantity shipped, with Ohio second and West Virginia third. The average carrying charges were $37 \mathrm{c}$ per cwt. for New York apples: 22c per cwt. for Ohio, and $19 \mathrm{c}$ per cwt. for West Virginia, while ior Washington apples charges averaged $\$ 1.66$ per cwt.

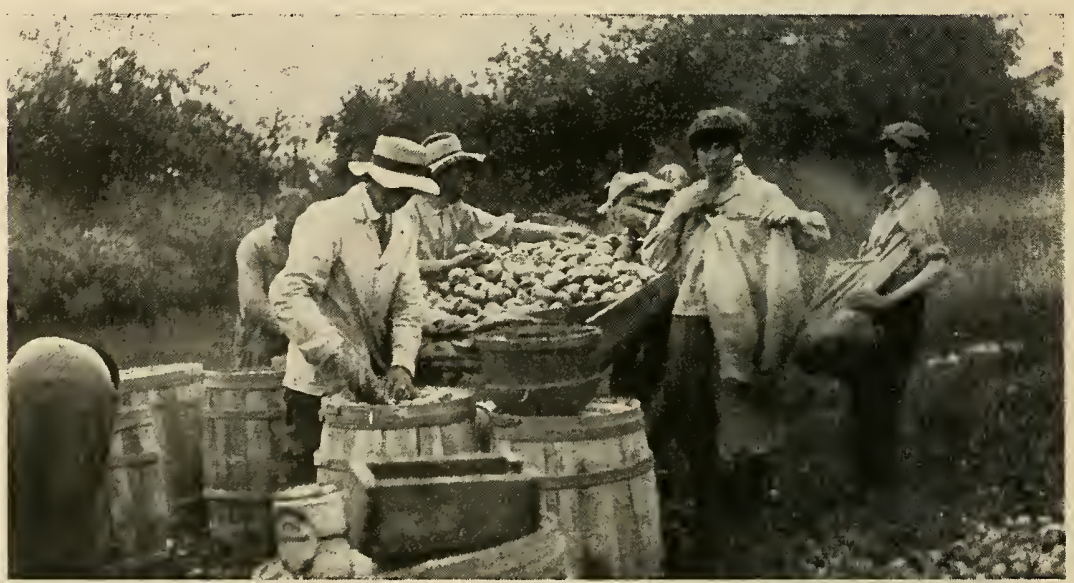

Packing apples for the local market. 
TABLE 12.- Receipts of Peaches in Wheeling by Freight: Origin of Shipment, Quantity, and Carrying Charges by Months, June, 1925, to May, 1926, Inclusive*

\begin{tabular}{|c|c|c|c|c|c|c|}
\hline \multirow{3}{*}{ Orizin of shipment } & \multirow{2}{*}{\multicolumn{2}{|c|}{ Tota1 }} & \multicolumn{4}{|c|}{1225} \\
\hline & & & \multicolumn{2}{|c|}{ June } & \multicolumn{2}{|c|}{$.5 u 1 y$} \\
\hline & Poumuin & $\begin{array}{l}\text { arrylna } \\
\text { cliarken }\end{array}$ & Pounde & $\begin{array}{l}\text { Carryingr } \\
\text { Ch:irges }\end{array}$ & Ponnds: & $\begin{array}{l}\text { Carrving } \\
\text { Charyen }\end{array}$ \\
\hline Total & 2181587 & 29080.54 & 180000 & $\$ 2624.36$ & 700000 & $\$ 10332.40$ \\
\hline Georgia & $92030 \mathrm{r}$ & $13595.5 \mathrm{C}$ & 180000 & $262+.36$ & 700000 & 10332.40 \\
\hline North Carolina & 80000 & $1152.5 n$ & $-\cdots--$ & $-\cdots--$ & $---n-$ & - \\
\hline Delaware & 27800 & 485.29 & $-\ldots .$. & $\ldots \ldots$ & $-\ldots---$ & - - - \\
\hline California & 10410! & 2545.08 & $-\cdots-n$ & ------ & ----- & ----- \\
\hline New Jersey _. & 181839 & 171.7 .91 & $-\cdots--$ & ----- & ----- & ---- \\
\hline Arkansas & 20571 & 350.61 & $\ldots \ldots$ & $\cdots---$ & $\ldots-\cdots$ & $\ldots$ \\
\hline Tennessee _.... & 180000 & 1962.95 & $-\ldots$ & $--\infty--$ & 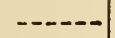 & $-\cdots$ \\
\hline New York & 354992 & 32.96 .24 & $--\cdots$ & ----- & $-\cdots--$ & $--\cdots \infty$ \\
\hline Ohio & 312276 & 2974.40 & $-\ldots$ &.----- & $\ldots$ & $-\cdots$ \\
\hline
\end{tabular}

1925

origln of Shlpment

Total

Georgia -.........

North Carolina

Delaware

California

New Jersey

Arkansas

Tennessee

New York

Ohio

\begin{tabular}{|c|c|c|c|c|c|}
\hline \multicolumn{6}{|c|}{1925} \\
\hline \multicolumn{2}{|c|}{ A urust } & \multicolumn{2}{|c|}{ september } & \multicolumn{2}{|c|}{ Oetulier } \\
\hline Poundsy & $\begin{array}{l}\text { Tarrying } \\
\text { Charges }\end{array}$ & Pounds & $\begin{array}{l}\text { Carrying } \\
\text { Clurises }\end{array}$ & Pounds & $\begin{array}{l}\text { Canrying } \\
\text { Charzes }\end{array}$ \\
\hline 529619 & $\$ 7443.03$ & 652009 & $\$ 6471.34$ & 119959 & $\$ 1209.41$ \\
\hline 40000 & 638.80 & - - & ----- & --- & --- \\
\hline 80000 & 1152.50 & -- & --- & $-\ldots-$ & 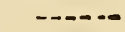 \\
\hline 27800 & 35.29 & & $\ldots$ & -.... & $\ldots$ \\
\hline 78073 & 1787.07 & 26036 & 758.01 & $\ldots$ & מ-. \\
\hline 103175 & 1065.81 & 78661 & 652.10 & -.....- & $-\infty-\infty$ \\
\hline 20571 & 350.61 & $-\cdots$ & $-\cdots$ & $-\ldots$ & $\ldots$ \\
\hline 180000 & 1962.95 & - - - & 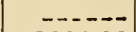 & ...-- & $-\ldots$ \\
\hline -..... & $\ldots-\cdots$ & $33350 \delta$ & 3980.98 & 21394 & 215.26 \\
\hline$-\ldots$ & $-\ldots-$. & 213701 & 1980.25 & 98575 & 994.15 \\
\hline
\end{tabular}

*No receipts in months of November, 1925, to May, 1926.

\section{Grapes}

Table 14 shows the receipts of $3,747,822$ pounds of grapes, with carrying charges amounting to $\$ 69,294.44$. The larger part of these shipments came from California.

Reports from local farmers indicate that grapes do quite well in this area, and if the preference for the California varieties is not too strong, there seems to be an opportunity for profitable grape culture in this section. California grapes compete with locally-grown and New York grapes during September and October.

\section{Melons}

From Table 15 it may be noted that local melon production does not meet the demand even in the height of the local season. In Sep- 


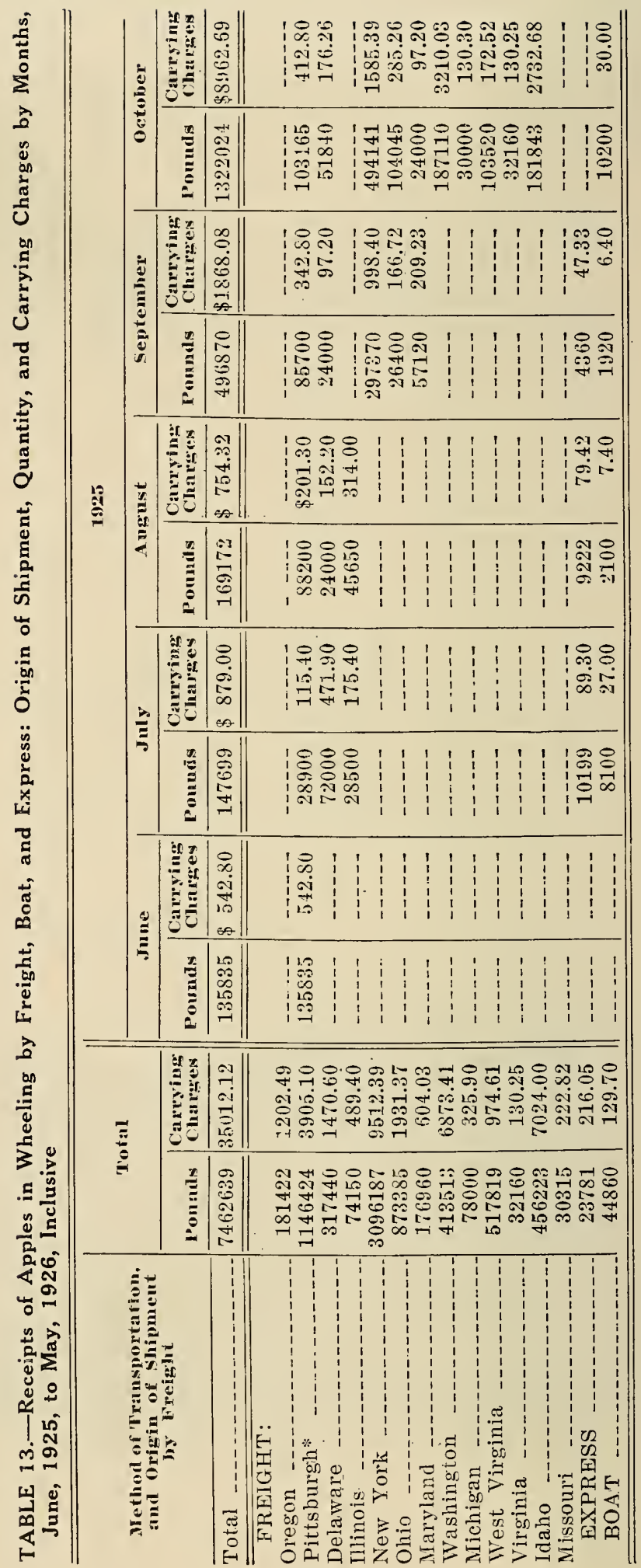


TABLE 14.-Receipts of Grapes in Wheeling by Freight: Origin of Shipment, Quantity, and Carrying Charges by Months, June, 1925, to May, 1926, Inclusive

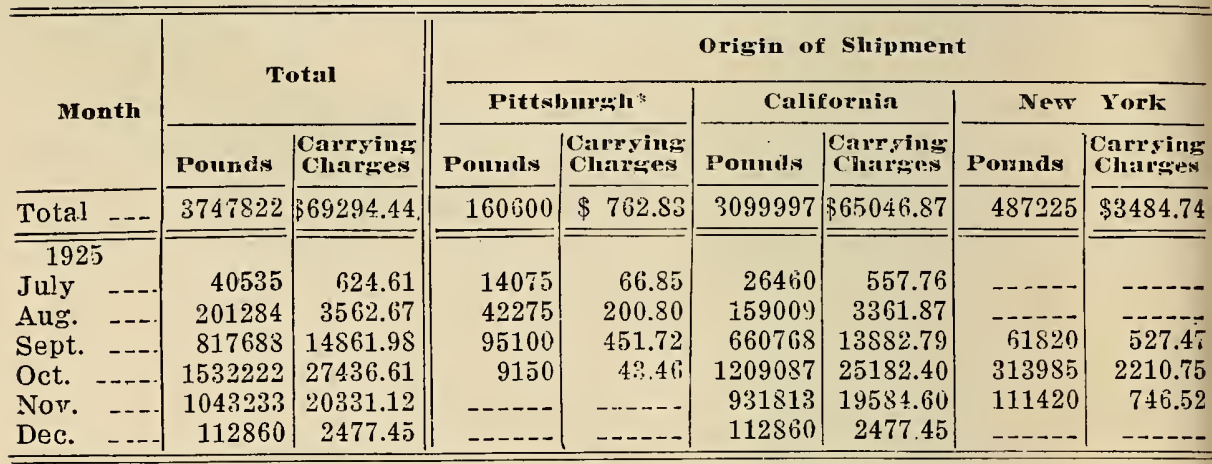

*Whoiesale niarket.

$\dagger$ No receipts in months of June, 1925, and January to May, 1926.

TABLE 15.-Melon Receipts in Wheeling by Freight: Origin of Shipment, Quantity and Carrying Charges by months, Jane, 1925, to May, 1926, Inclusive*

\begin{tabular}{|c|c|c|c|c|}
\hline \multirow[t]{2}{*}{ Origin of Shipment } & \multicolumn{2}{|c|}{ T'ot:11 } & \multicolumn{2}{|c|}{$\frac{1925}{\text { Jnme }}$} \\
\hline & Pounuds & $\mid \begin{array}{l}\text { Canrxing } \\
\text { Clharges }\end{array}$ & Ponnds & $\mid \begin{array}{l}\text { Carryings } \\
\text { Charsess }\end{array}$ \\
\hline Total & 4084200 & $\$ 250749.30$ & 363000 & $\$ 2498 . \$ 9$ \\
\hline Florida & 391600 . & 2827.04 & 82500 & $605.2 \%$ \\
\hline Georgia & 2982100 & $18943.6^{\circ} 2$ & $2 \times 050$ & 1893.62 \\
\hline Alabama & 56500 & 381.32 & ----- & ---- \\
\hline South Carolina & 361500 & 2123.59 & ---- & $---\cdots$ \\
\hline Indiana & 208700 & 1098.81 & ----- & $\ldots-\cdots$ \\
\hline Virginia & 25200 & 157.20 & $-\cdots-\cdots$ & 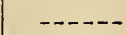 \\
\hline West Virginia & 25200 & $\overline{2} 2.92$ & ----- & $-\ldots-1$ \\
\hline Delaware & 33100 & 158.80 & $---\cdots$ & $-\rightarrow---$ \\
\hline
\end{tabular}

\begin{tabular}{|c|c|c|c|c|c|c|}
\hline \multirow{3}{*}{ Origin of Shipment } & \multicolumn{6}{|c|}{ דבש: } \\
\hline & \multicolumn{2}{|c|}{ July } & \multicolumn{2}{|c|}{ A uguist } & \multicolumn{2}{|c|}{ Septemliex } \\
\hline & Pounds & $\begin{array}{l}\text { Carryings } \\
\text { Churses }\end{array}$ & Porands & $\begin{array}{l}\text { Carrying } \\
\text { Charges }\end{array}$ & Punuds & $\begin{array}{l}\text { Carrying } \\
\text { Charates }\end{array}$ \\
\hline Total & 1974700 & $\$ 12924.17$ & 1527400 & .9221 .28 & 219100 & $\$ 1103.96$ \\
\hline Florida & 309100 & 2221.77 & $-\ldots-n$ & $----\cdots$ & $\cdots---\infty$ & ----- \\
\hline Georgia & 1425400 & .9257 .50 & 1215500 & 7431.40 & 61000 & 365.80 \\
\hline Alabama & 56500 & $: 381.29$ & $---\cdots$ & ----- & ----- & $-\cdots-\cdots$ \\
\hline South Carolina & 159700 & 938.43 & 2018110 & $11 \leqq ! .11$ & ----- & ------ \\
\hline Indiana & $\$ 4009$ & 124.80 & 84900 & 447.57 & 99809 & 526.44 \\
\hline Virginia & - - - - & $\cdots+\cdots$ & 25200 & 157.20 & $-----\cdot$ & ----- \\
\hline West Virginia _... & ----- & $\ddot{-n-\infty}$ & ----- & $-m-n$ & 25200 & 52.92 \\
\hline Delaware & $\ldots---$ & ----- & $-\cdots-\infty$ & ----- & 32100 & 153.80 \\
\hline
\end{tabular}

*No receipts in months of October, 1925 , to May, 1926. 
tember 219100 pounds of melons were shipped to the Wheeling market. Only about one eighth of these came from West Virginia, and none from Ohio.

\section{Meat}

Table 16 show's the receipts of meat on the Wheeling market. The greater part came from Chicago, Columbus, and Pittsburgh. There is a fair-sized packing plant in Wheeling, as may be judged from receipts of cattle as shown in Table 17 and of hogs as shown in Table 18.

TABLE 16.-Receipts of Meats in Wheeling by Freight: Quantity and Carrying Charges by Months, June, 1925, to May, 1926, Inclusive

\begin{tabular}{|c|c|c|}
\hline Yonth & Quantity in l'ommis & Carrying Chareses \\
\hline Total $\ldots \ldots$ & 15047596 & $\$ \$ 1818.59$ \\
\hline $\begin{array}{l}1925 \\
\text { June } \\
\text { July } \\
\text { August } \\
\text { September } \\
\text { October } \\
\text { November } \\
\text { December } \\
\quad 1926 \\
\text { January } \\
\text { February } \\
\text { March } \\
\text { April } \\
\text { May }\end{array}$ & $\begin{array}{r}1317856 \\
1376390 \\
1526061 \\
1131799 \\
1387281 \\
1187598 \\
1210118 \\
\\
1348239 \\
1282689 \\
1419670 \\
841809 \\
1018053\end{array}$ & $\begin{array}{l}6877.52 \\
7663.99 \\
7933.30 \\
6221.75 \\
7304.35 \\
6105.31 \\
6372.30 \\
\\
7476.93 \\
7186.03 \\
7588.62 \\
5231.21 \\
5857.28\end{array}$ \\
\hline
\end{tabular}

TABLE 17.- Receipts of Cattle in Wheeling by Freight and Express: Quantity and Carrying Charges by Months, June, 1925, to May, 1926, Inclusive

\begin{tabular}{|c|c|c|}
\hline Yonth & Quantity in Pounds & Carrying Charges \\
\hline Total _..... & 15396301 & $\$ 70990.36$ \\
\hline $\begin{array}{l}1925 \\
\text { June } \\
\text { July } \\
\text { August } \\
\text { September } \\
\text { October } \\
\text { November } \\
\text { December } \\
\quad 1926 \\
\text { January } \\
\text { February } \\
\text { March } \\
\text { April } \\
\text { May }\end{array}$ & $\begin{array}{r}603939 \\
974999 \\
977574 \\
1159863 \\
612116 \\
1089181 \\
1320712 \\
\\
1764133 \\
1831322 \\
2216463 \\
1387379 \\
1458721\end{array}$ & $\begin{array}{r}292 \times .07 \\
3705.61 \\
436 . .43 \\
4715.88 \\
6160.02 \\
3468.89 \\
5539.59 \\
8614.95 \\
\\
8156.93 \\
10540.77 \\
6090.49 \\
6705.73\end{array}$ \\
\hline
\end{tabular}




\section{Grain and Mill Feed}

Table 19 shows the receipts of grain and mill feed received on the Wheeling market. The Wheeling area is not well adapted to grain production, topography and price of land considered. It is probably more economical for dairymen to buy the bulk of their feed than to attempt to raise it on high-priced land and with high-priced labor.

TABLE 18.- - Receipts of Hogs in Wheeling by Freight: Quantity and Carrying and Feed Charges by Months, June 1925, to May, 1926, Inclusive

\begin{tabular}{|c|c|c|}
\hline Month & Ruantity in Pounls & Carrying Chatuses \\
\hline Total _...... & 65635945 & $\$ 302630.99$ \\
\hline 1925 & & \\
\hline June & 7367970 & 57136.45 \\
\hline July & 6102950 & 38793.97 \\
\hline August & 5227081 & $199 \$ 4.98$ \\
\hline September & 5971(iう) & $21750 \overline{.83}$ \\
\hline October & 5475900 & 19536.27 \\
\hline November & 5418470 & 19430.68 \\
\hline $\begin{array}{l}\text { December } \\
1926\end{array}$ & 5483951 & 19951.12 \\
\hline January & 5846279 & 22196.36 \\
\hline February & 4699662 & 18556.87 \\
\hline March & 5238306 & 22428.77 \\
\hline April _. & 4660760 & 22020.71 \\
\hline May & 4148959 & 20838.98 \\
\hline
\end{tabular}

TABLE 19.- Receipts of Grain and Mill Feed in Wheeling by Freight: Quanfity and Carrying Charges by Months, June, 1925, to May, 1926, Inclusive

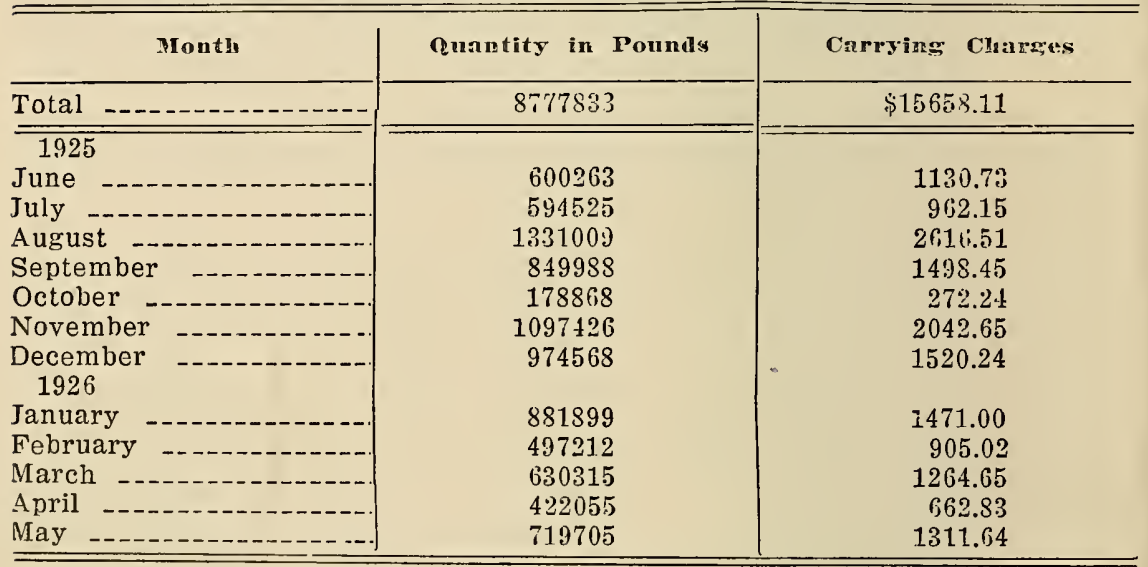




\section{SUMMARY}

Records of freight, express, and boat receipts show that food commodities are coming to the Wheeling market in large quantities, from distant points and with high freight costs.

Approximately 316,000 bushels of potatoes were brought to the Wheeling market by boat, express, and freight. West Virginia farmers supplied only 1.4 percent of this total and only 3.7 percent of the potatoes received during the four-months' period, August, September, October, and November, which is the peak of the marketing season for locally grown potatoes. The average carrying charges on the potatoes received on the market amounted to $50 \mathrm{c}$ per cwt., while for those potatoes coming from West Virginia the carrying charges amounted to $28 \mathrm{c}$ per cut. Prices are favorable for locally grown potatoes.

West Virginia potato growers have scarcely touched the Wheeling potato market. It would seem advisable that steps be taken to open this market for state-grown potatoes.

Large quantities of onions, cabbage, and lettuce came on the market. The market is available but not enough data were collected in this study to hazard advice on the profitableness of the culture of these vegetables locally.

The data show that local production of beans and tomatoes tairly well supplies the market demands for these vegetables during the local producing season.

Poultry production for the local market could stand some expansion before local demands are satisfied.

It would appear that the culture of grapes and small fruits might well take a place on some farms in the area.

While orcharding appears to be over-expanded in the country as a whole, there seems to be an opportunity for farmers in the northern panhandle section to produce apples at a fair profit for local nurkets. 


\section{DISCUSSION}

Data on agricultural production costs in the Wheeling area together with comparative costs in the main competing areas are essential in guiding readjustments. A cooperative study by Ohio, Pennsylvania, and West Virginia would be necessary to obtain these data. The present study has gone no further than to point out some of the possibilities of readjustments. It should point the way to more detailed studies of the possibilities for producing locally the various crops for which the local market shows an unfilled demand.

Farmers in the Wheeling area have an advantage in transportation costs because of nearness to market. Yet further study might show that increased production costs would wipe out this advantage in the case of some or all of the commodities considered.

Truck farming appears to be losing in favor in the area, but no definite reason for this circumstance was ascertained.

Dairy farming for market milk production appears to be overdeveloped. If dairymen find that they cannot produce milk for sale at the price of manufactured milk, they may find it profitable to change to other sorts of production. The road system has opened up a large section of cheaper land than is to be found in Ohio County. Consequently more and more of the fluid milk is becoming surplus milk and has to go at manufactured-milk prices.

Dairy farmers in the Wheeling area are in need of a thorough study of milk production and marketing.

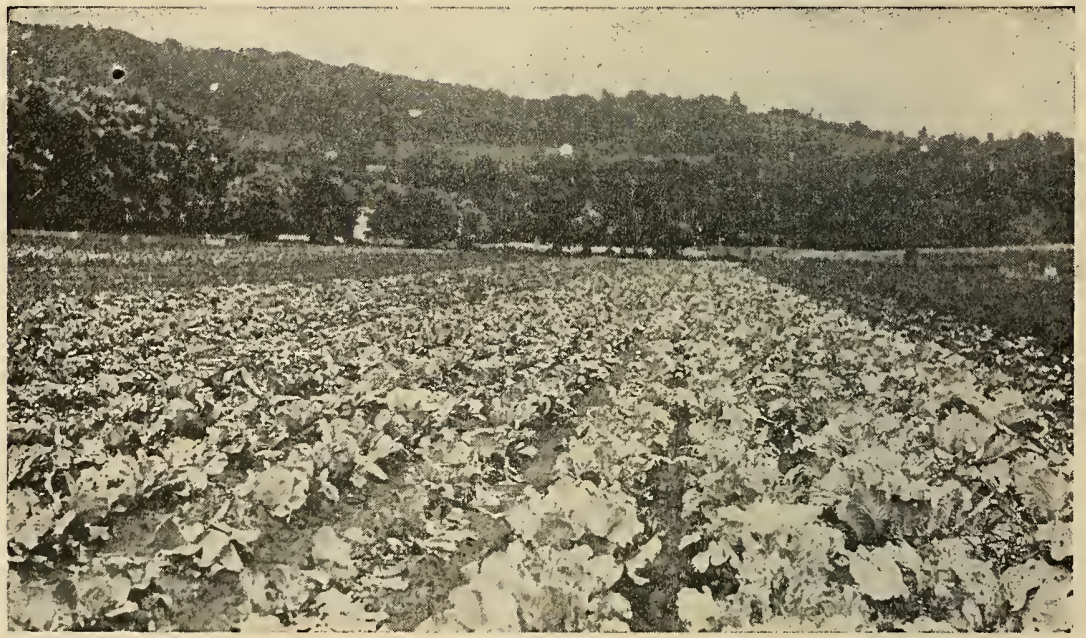

Much cabbage is grown for the local market. 



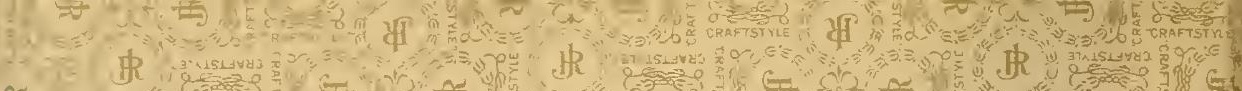

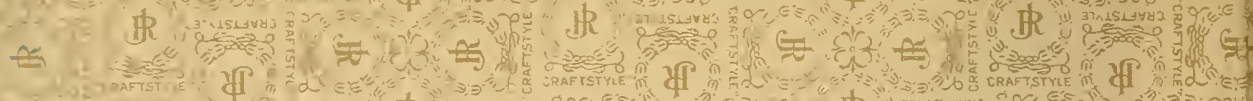

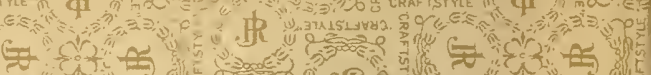

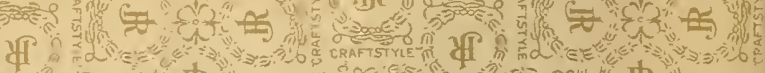

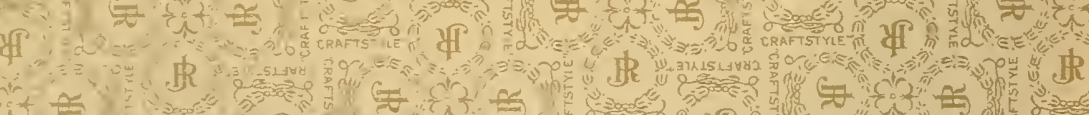

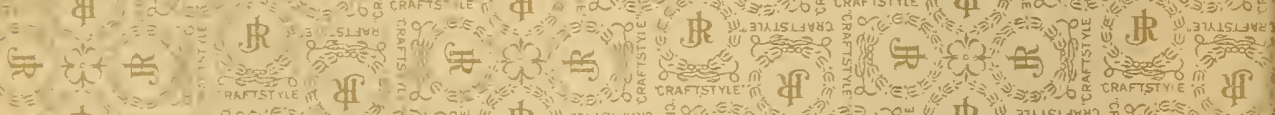
gan

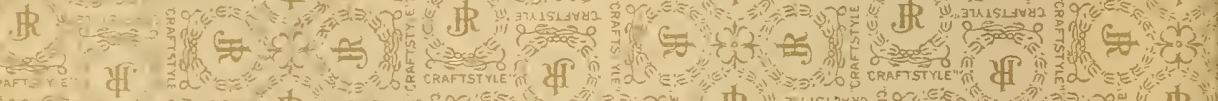

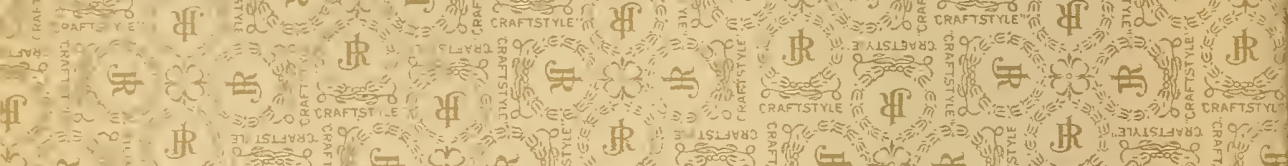
$\begin{array}{lll}A & =1\end{array}$ 

al' $=0$.

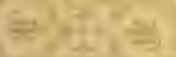
148
A

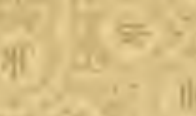
in

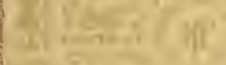
$k-x$

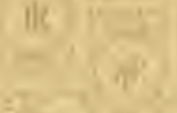

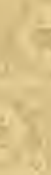
4
10
41
(11)
$\sqrt{5}$

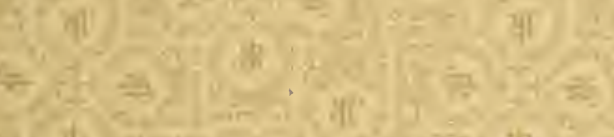
Uiv

(1)

Fopting

91 .

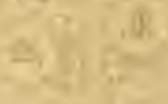

1

in

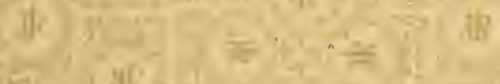

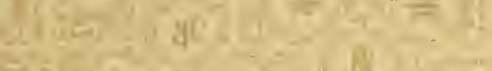

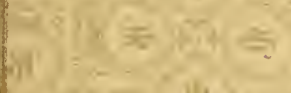

if

k

$v^{\prime}$

(19) $3=$

$x^{41}$

12

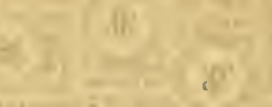

$1=$

II'

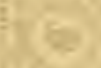

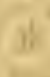

1)

Ik

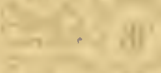

(1)

$1=$

2)

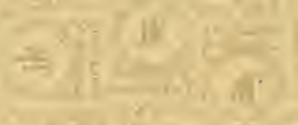

$y_{1 \times 2}=$

(1)

8II

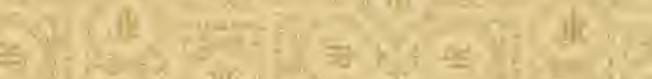

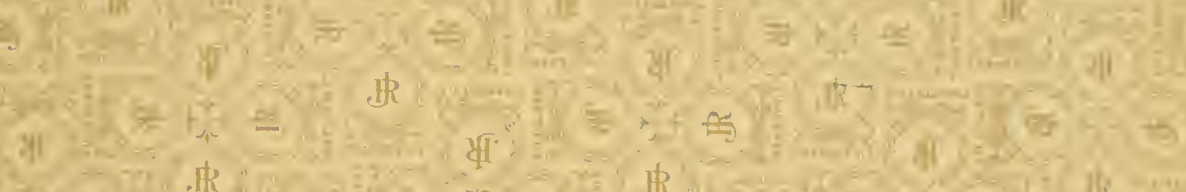

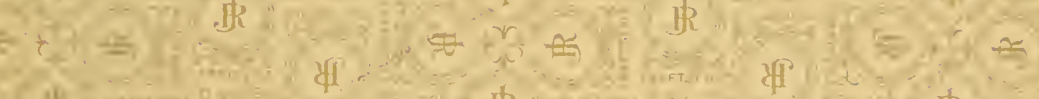

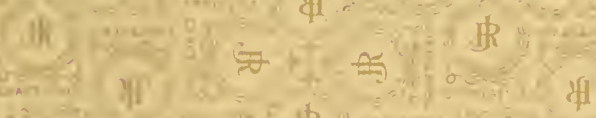

Wi

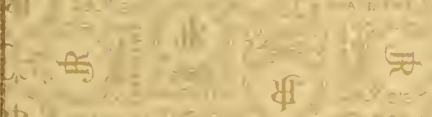

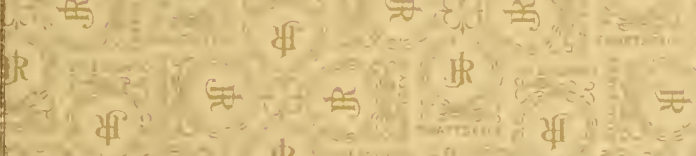

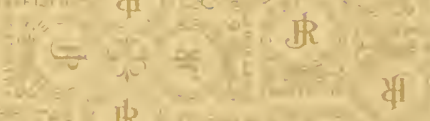

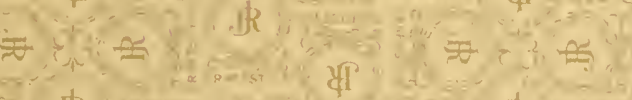

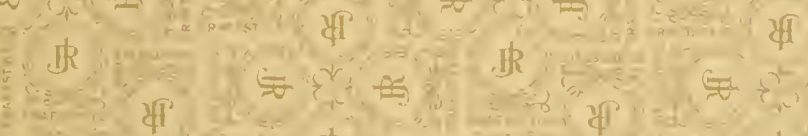

s.

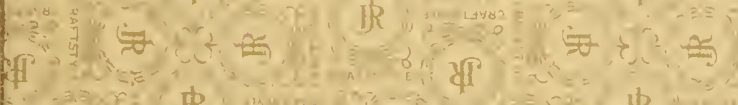

$\Rightarrow$ 穴

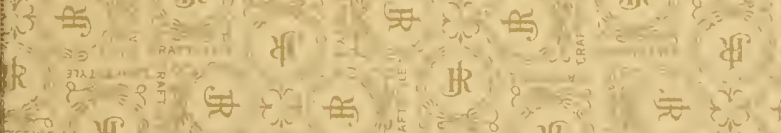

E ET या

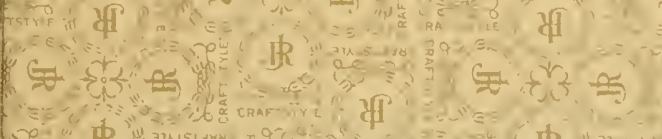

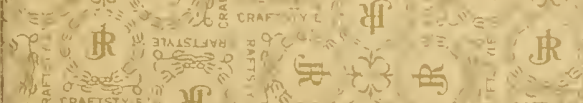

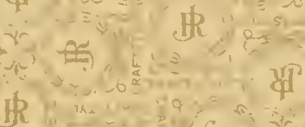

F. $18=$

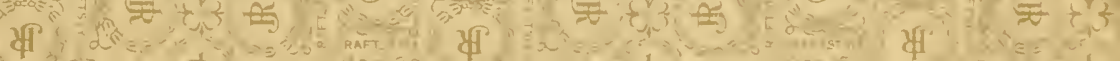


